\title{
Nilai Pendidikan Karakter dalam Dialog Tokoh Cenk-Blonk dalam Lakon Gatutkaca Duta dan Penerapannya Oleh Guru pada Pembelajaran Bahasa Indonesia
}

\author{
Pt. Agus Suyasa ${ }^{1}$, I Nengah Suandi ${ }^{2}$ \\ ${ }_{1,2}$ Program Studi Pendidikan Bahasa Program Pascasarjana \\ Universitas Pendidikan Ganesha \\ Singaraja, Indonesia \\ e-mail: agus.suyasa@pasca.undiksha.ac.id ${ }^{1}$, nengah.suandi@pasca.undiksha.ac.id ${ }^{2}$
}

\begin{abstract}
Abstrak
Penelitian ini bertujuan untuk mendeskripsikan (1) nilai pendidikan karakter dalam dialog tokoh Cenk dan Blonk dalam wayang Cenk Blonk berjudul Gatutkaca Duta, dan (2) Mendeskripsikan penerapan nilai-nilai pendidikan karakter dalam dialog tokoh Cenk dan Blonk oleh guru di SMP 3 Denpasar baik dalam perencanaan pembelajaran, pelaksanaan pembelajaran, dan evaluasi pembelajaran. .Penelitian ini menggunakan rancangan penelitian kualitatif. Subjek penelitian ini adalah guru Bahasa Indonesia kelas VII, VIII, dan IX SMPN 3 Denpasar, dan objek penelitian ini adalah dialog-dialog tokoh Cenk dan Blonk yang bernilai pendidikan karakter dan alternatif materi pembelajaran nilai-nilai pendidikan karakter dalam dalam perencanaan pembelajaran, pelaksanaan pembelajaran, dan evaluasi pembelajaran. Metode yang digunakan untuk mengumpulkan data adalah metode dokumentasi (untuk memeroleh data dialog tokoh Cenk dan Blonk), observasi (untuk memeroleh data alternatif materi pembelajaran nilai-nilai pendidikan karakter dalam dialog tokoh Cenk dan Blonk oleh guru di SMP 3 Denpasar baik dalam perencanaan pembelajaran, pelaksanaan pembelajaran, dan evaluasi pembelajaran), dan metode wawancara (untuk memeroleh data hambatan guru dalam menerapkan nilai pendidikan karakter dalam pembelajaran Bahasa Indonesia).Metode analisis data yang digunakan adalah analisis deskriptif kualitatif.
\end{abstract}

Kata kunci :pendidikan karakter, penerapan pada pembelajaran Bahasa Indonesia

\begin{abstract}
This study aimed to describing (1) the character education value in Cenk and Blonk dialogues in Cenk Blonk traditional leather puppet titled "Gatutkaca Duta" performance, (2) the aplication of character education by the teacher in the planning, action (activities), and evaluate, in Indonesian learning prosses at SMPN 3 Denpasar. This study is using the qualitative research planning. The subject of this study were Indonesian teachers, and the object of this study was Cenk and Blonk dialogues. The methods used in collecting data were documentation (to obtain data of Cenk Blonk dialogues), observation (to obtain data of the material subject alternative of education character values in Indonesian learning prosses), and interview (to obtain data of the teachers inhibition in implementing the character education values). The data were analyzed by using the descriptive qualitative method.
\end{abstract}

Keywords: Character Education Value, The Apliication In Indonesian Learning Prosses 


\section{Pendahuluan}

Pendidikan memiliki peran penting dalam kehidupan manusia. Salah satunya sebagai media yang berfungsi menjadikan manusia lebih baik dari sebelumnya. Peran penting lainnya adalah untuk memanusiakan manusia.'Pendidikan adalah sebuah usaha yang ditempuh oleh manusia dalam rangka memperoleh ilmu yang kemudian dijadikan sebagai dasar untuk bersikap dan berperilaku. Karena itu, pendidikan merupakan salah satu proses pembentukan karakter manusia. Dalam keseluruhan proses yang dilakukan manusia terjadi proses pendidikan yang akan menghasilkan sikap dan perilaku yang akhirnya menjadi watak, kepribadian, atau karakternya. Untuk meraih derajat manusia seutuhnya sangatlah tidak mungkin tanpa melalui proses pendidikan.

Tohir (2014) mengatakan bahwa, pendidikan juga merupakan usaha masyarakat dan bangsa dalam mempersiapkan generasi mudanya bagi keberlangsungan kehidupan masyarakat dan bangsa yang lebih baik di masa depan. Keberlangsungan itu ditandai oleh pewarisan budaya dan karakter yang telah dimiliki masyarakat dan bangsa. Dalam proses pendidikan budaya dan karakter bangsa, secara aktif peserta didik mengembangkan potensi dirinya, melakukan proses internalisasi, dan penghayatan nilai-nilai menjadi kepribadian mereka dalam bergaul di masyarakat, mengembangkan kehidupan masyarakat yang lebih sejahtera, serta mengembangkan kehidupan bangsa yang bermartabat.

Dalam pembelajaran Bahasa Indonesia SMP berkurikulum 2013, pendidikan karakter sudah dicantumkan di dalam silabus pembelajaran Bahasa Indonesia. Pendidikan karakter tersebut terlihat di dalam Kompetensi Inti (KI) di dalam Silabus dan RPP tersebut. KI 1 berbunyi, "Menghargai dan menghayati ajaran agama yang dianutnya", KI 2 berbunyi "Menghargai dan menghayati perilaku jujur, disiplin, tanggungjawab, peduli (toleransi, gotong royong), santun, percaya diri, dalam berinteraksi secara efektif dengan lingkungan sosial dan alam, dalam jangkauan pergaulan dan keberadaannya". Berdasarkan pada kedua Kompetensi Inti di dalam silabus tersebut, terlihat bahwa penanaman nilai-nilai karakter di dalam pembelajaran bahasa Indonesia, sudah diterapkan. Pelaksanaan pembelajaran Bahasa Indonesia di dalam kelas, juga berdasarkan pada Kompetensi Inti tersebut, yang digunakan sebagai acuan untuk kompetensi-kompetensi lainnya.

Penguatan pendidikan moral (moral education) atau pendidikan karakter (character education) dalam konteks sekarang sangat relevan untuk mengatasi krisis moral yang sedang melanda generasi muda kita, terutama para siswa dikalangan sekolah, baik itu di tingkat menengah (SMP) sampai ke perguruan tinggi (PT). Krisis tersebut antara lain berupa meningkatnya pergaulan bebas, maraknya angka kekerasan anak-anak dan remaja, kejahatan terhadap teman, pencurian remaja, kebiasaan menyontek, penyalahgunaan obat-obatan, pornografi, sudah menjadi masalah sosial yang hingga saat ini belum dapat diatasi secara tuntas, oleh karena itu betapa pentingnya pendidikan karakter.

Selain didapat dalam ranah pendidikan formal dan nonformal, pendidikan karakter dapat pula didapat melalui ranah seni, baik kesenian secara tertulis, ataupun kesenian secara lisan. Kesenian-kesenian tersebut secara tidak langsung juga mengajari kita tentang karakter-karakter yang baik dan buruk. Wacana-wacana berpendidikan karakter juga secara tidak langsung terselip di dalam pesan-pesan yang disampaikan oleh pengarang atau pencerita di dalam sebuah konteks kesenian.

Salah satu mata pelajaran di dalam sistem pendidikan di negara kita adalah mata pelajaran Bahasa Indonesia. Kaitan antara pendidikan karakter dan pembelajaran Bahasa Indonesia dapat dilihat di dalam silabus pembelajaran Bahasa Indonesia, yaitu di dalam silabus pembelajaran Bahasa Indonesia yang berkurikulum 2013 (Kurtilas). Pendidikan karakter di dalam silabus pembelajaran Bahasa Indonesia, terlihat di Kompetensi Inti (KI 1, dan KI 2).

Selain di dalam pembelajaran, khususnya pembelajaran Bahasa Indonesia, dunia kesenian, utamanya seni pewayangan, juga bisa digunakan sebagai media penanaman nilainilai pendidikan karakter. Salah satunya adalah seni pewayangan inovatif Cenk Blonk dari desa Belayu, Kecamatan Marga, Kabupaten Tabanan. Seni pewayangan Cenk Blonk ini sarat akan petuah-petuah seperti pertunjukan wayang lainnya, akan tetapi, keinovatifan wayang Cenk Blonk adalah munculnya tokoh-tokoh kunci di setiap jalan cerita yang dibawakan. Tokoh-tokoh kunci yang menjadi idola dan maskot wayang Cenk Blonk adalah tokoh Cenk dasn tokoh Blonk. Dialog-dialog antara kedua tokoh tersebut selalu dinantikan oleh penonton, karena, dialogdialog tersebut sebenarnya sarat akan petuah-petuah kehidupan, terutama kehidupan sosial masyarakat saat ini. Dan hal ini, tidak terlepas pula dari penggalian nilai-nilai karakter di setiap dialog tokoh Cenk dan Blonk. 
Keterkaitan antara pendidikan, kurikulum pembelajaran Bahasa Indonesia, dan nilai-nilai karakter dalam dialog tokoh Cenk dan Blonk adalah pada pemilihan dan penggunaan nilai-nilai karakter yang terdapat di dalam dialog tokoh Cenk dan Blonk sebagai alternatif materi pada pembelajaran Bahasa Indonesia di dalam kelas, terutama pada tingkat Sekolah Menengah Pertama. penerapan ini bisa dilihat pada proses perencanaan pembelajaran Bahasa Indonesia, proses pelaksanaan pembelajaran Bahasa Indonesia, dan proses penilaian pembelajaran Bahasa Indonesia.

Relevansi antara nilai-nilai pendidikan karakter tersebut, bisa juga digunakan sebagai alternatif materi pembelajaran nilai karakter bangsa di dalam proses pengajaran bahasa di sekolah-sekolah, utamanya di sekolah menengah pertama. Karena, nilai-nilai pendidikan karakter cukup relevan dengan pengajaran bahasa, yaitu, adanya karakter-karakter yang mampu meningkatkan kesadaran dan sikap berbahasa yang baik dari setiap peserta didik di sekolah menengah pertama, yang tentunya juga bisa berpengaruh dalam upaya penanaman karakter dari generasi bangsa dalam usaha menekan degradasi moral pada pebelajar.

Persoalan pendidikan karakter atau moral tidak sepenuhnya terabaikan oleh lembaga pendidikan. Akan tetapi, dengan fakta-fakta seputar kemerosotan karakter pada sekitar kita menunjukkan bahwa ada kegagalan pada institusi pendidikan kita dalam hal menumbuhkan manusia Indonesia yang berkarakter atau berakhlak mulia. Untuk itu, kondisi dan fakta kemerosotan karakter dan moral yang terjadi menegaskan bahwa para guru yang mengajar mata pelajaran apa pun harus memiliki perhatian dan menekankan pentingnya pendidikan karakter pada para siswa. Sehingga, pendidikan karakter tersebut sangatlah penting di dalam proses belajar mengajar di sekolah. Dan hal tersebut bisa dimulai dari tahapan perencanaan pembelajaran, pelaksanaan pembelajaran, sampai pada tahap evaluasi pembelajaran.

Masalah yang akan dikaji dalam penelitian ini adalah, nilai-nilai pendidikan karakter apa saja yang terdapat di dalam dialog-dialog tokoh Cenk dan Blonk dalam pementasan seni wayang Cenk Blonk yang berjudul Gatotkaca Duta dan bagaimanakah alternatif materi pembelajaran nilai-nilai pendidikan karakter dalam dialog-dialog tokoh Cenk dan Blonk dalam pementasan seni wayang Cenk Blonk yang berjudul Gatotkaca Duta pada pembelajaran bahasa Indonesia oleh guru di SMPN 3 Denpasar baik dalam perencanaan pembelajaran, pelaksanaan pembelajaran, dan evaluasi pembelajaran.

Penelitian ini adalah penelitian deskriptif kualitatif yang bertujuan untuk mengetahui, (1) Mendeskripsikan nilai-nilai pendidikan karakter dalam dialog tokoh Cenk dan Blonk pada pementasan seni wayang Cenk Blonk berjudul Gatotkaca Duta. (2) Mendeskripsikan nilai-nilai pendidikan karakter dalam dialog tokoh Cenk dan Blonk pada pementasan seni wayang Cenk Blonk berjudul Gatotkaca Duta sebagai alternative materi pada pengajaran bahasa Indonesia di SMP 3 Denpasar baik dalam perencanaan pembelajaran, pelaksanaan pembelajaran, dan evaluasi pembelajaran.

\section{Metode}

Penelitian mengenai dialog-dialog tokoh Cenk dan Blonk dalam seni pementasan wayang inovatif Cenk Blonk merupakan salah satu penelitian yang menggunakan rancangan penelitian jenis kualitatif. Sukardi (dalam Habiburrahman,2014;75) mengatakan bahwa penelitian jenis kualitatif bertujuan untuk memaparkan data sebagaimana adanya.

Penelitian ini menggunakan pendekatan deskriptif kualitatif. Dengan pendekatan deskriptif kualitatif, data dijelaskan atau dipaparkan dan diuraikan sesuai dengan sifat alamiah data tersebut, yaitu dengan cara menuturkan, mengklasifikasi, dan menganlisisnya. data akan digambarkan atau dilukiskan secara sistematis, faktual, dan akurat sesuai dengan sifat dan hubungan fenomenanya. Dengan demikian, penelitian nilai-nilai pendidikan karakter dalam dialog tokoh Cenk dan Blonk dan relevansinya pada pembelajaran Bahasa Indonesia di SMP Negeri 3 Denpasar sesuai dengan pendekatan kualitatif yang memiliki sifat alamiah, faktual, dan akurat yang mengungkap fenomena relevansi atau keterkaitan nilai-nilai pendidikan karakter dalam dialog tokoh Cenk dan Blonk dengan pembelajaran Bahasa Indonesia di dalam kelas dari segi perencanaan, pelaksanaan, dan evaluasi pembelajaran.

Subjek penelitian ini adalah guru pengajar Bahasa Indonesia kelas VII, VIII, dan IX, dan objek penelitian ini adalah dialog-dialog tokoh Cenk dan Blonk yang relevan dengan pembelajaran Bahasa Indonesia baik dalam perencanaan, pelaksanaan, dan evaluasi pembelajaran. Metode pengumpulan data yang digunakan dalam penelitian ini adalah (1) metode dokumentasi, (2) metode observasi, dan (3) metode wawancara. 
Data dalam penelitian ini diambil dengan menggunakan metode dokumentasi yang digunakan untuk mendata dialog-dialog tokoh Cenk dan Blonk yang mengandung nilai pendidikan karakter dalam lakon wayang Cenk Blonk berjudul Gatutkaca Duta. Metode observasi digunakan untuk mendata penerapan nilai-nilai pendidikan karakter yang ditemukan di dalam dialog tokoh Cenk dan Blonk yang diterapkan oleh guru pengajar Bahasa Indonesia di kelas VII, VIII, dan IX, baik dalam perencanaan pembelajaran (RPP), pelaksanaan pembelajaran di dalam kelas, dan dalam tahap evaluasi pembelajaran. Metode wawancara digunakan untuk mengetahui hambatan-hambatan guru dalam menerapkan nilai-nilai pendidikan karakter dalam pembelajaran Bahasa Indonesia.

Metode analisis data dalam penelitian ini antara lain, reduksi data adalah memilih data yang diperlukan, dan data yang kurang penting akan disisi hkan. Data yang kurang penting akan dipertimbangkan lagi bila diperlukan. Reduksi data dilakukan mulai dari pengumpulan data di lapangan, hingga analisis setelah data terkumpulkan.

Data berupa transkrip dari dialog tokoh Cenk dan Blonk, data hasil observasi dan hasil wawancara dikumpulkan, kemudian data tersebut akan diidentifikasi, kemudian dikelompokkan sesuai dengan kedelapan belas jenis nilai pendidikan karakter tersebut, dan dicari relevansi atau keterkaitannya dengan pembelajaran Bahasa Indonesia di dalam kelas.

Setelah data tentang klasifikasi dialog yang bernilai pendidikan karakter tersebut disajikan dengan bagan analisis data yang terdapat di instrument analisis. Bagan analisis tersebut berupa bagan kerelevansian antara dialog bernilai pendidikan karakter pada dialog tokoh Cenk dan Blonk dengan pembelajaran Bahasa Indonesia di SMP N 3 Denpasar.

Pengujian keabsahan data dalam penelitian ini dimaksudkan untuk meningkatkan kepercayaan dan validitas data, sehingga tingkat kepercayaan temuan dapat dicapai. Ada kemungkinan unsur subjektivitas yang masuk ke dalam data penelitian. Apabila hal tersebut terjadi, maka data tersebut dikatakan tidak sah atau tidak valid. Untuk itu, peneliti perlu melakukan perpanjangan keikutsertaan, ketekunan, pengamatan, tringulasi, pengecekan teman sejawat, dan kecukupan refrensi.

Pertama, peneliti melakukan pengujian keabsahan data dengan memperpanjang keikutsertaan, Perpanjangan keikutsertaan yang dimaksud adalah memeperpanjang waktu pengumpulan data yang diperlukan dalam penelitian. Dalam hal ini, peneliti kembali mendokumentasikan ulang data tentang dialog-dialog tokoh Cenk dan Blonk yang mengandung nilai pendidikan karakter, dan mengidentifikasi lebih lanjut agar data yang diperoleh lebih valid.

Kedua, peneliti melakukan pengecekan keabsahan data dengan ketekunan pengamatan. Dalam hal ini, pada saat pengumpulan data, peneliti mengamati secara cermat hasil observasi guru pengajar Bahasa Indonesia di dalam kelas yang menerapkan nilai-nilai pendidikan karakter kepada siswanya, dan hasil wawancara yang telah terkumpul, sehingga data yang diperlukan dapat didentifikasi dan diklasifikasikan.

Ketiga, melakukan tringulasi terhadap metode penelitian. Dalam hal ini, peneliti mencermati kembali prosedur penelitian yng digunakan, membandingkan dengan metode penelitian sejenis yang sudah ada, dan mendiskusikannya dengan pihak-pihak yang berkompeten, yang sesuai dengan bidang ilmu yang dikaji daam penelitian ini. Pihak yang dianggap berkompeten adalah, teman sejawat dan dosen pembimbing. Dengan melakukan tringulasi terhadap metode tersebut, diharapkan penafsiran yang menyimpang atau salah tafsir tida terjadi.

Keempat, peneliti melakukan tringulasi terhadap sumber-sumber atau teori yang relevan. Dalam hal ini, peneliti membaca dan menelaah sumber-sumber pustaka yang relevan dengan masalah secara berulang-ulang agar diprleh pemahaman yang memadai. Dengan dmikian, diharapkan mampu menambah wawasan keilmuan dan mendalami teori yang ada, sehingga penelitian ini benar-benar relevan dengan studi pendidikan karakter dalam pembelajaran Bahasa Indonesia.

\section{Hasil dan Pembahasan}

Berdasarkan kutipan-kutipan dialog tokoh Cenk dan Blonk dengan tokoh lain dan juga kutipan-kutipan dialaog tokoh Cenk dengan Blonk, nilai karakter yang ditemukan sejumlah 9 nilai pendidikan karakter dari keseluruhan 18 nilai pendidikan karakter. Kesembilan nilai pendidikan karakter tersebut adalah, (1) Religius, (2) Kerja Keras (3) Demokratis, (4) Menghargai Prestasi, (5) Cinta Tanah Air, (6) Toleransi, (7) Peduli Sosial, (8) Cinta Damai, dan (9) Tanggung Jawab. 
Dari kesembilan nilai karakter yang ditemukan di dalam dialog tokoh Cenk dan Blonk tersebut, nilai karakter Kerja Keras (3 buah dialog) yang dominan muncul. Nilai karakter Kerja Keras adalah nilai karakter yang dominan muncul dalam pementasan wayangCenk Blonk yang berjudul Gatutkaca Duta. Nilai karakter tersebut muncul dalam tiga buah dialog antara tokoh Cenk dan Blonk, tokoh Blonk dan Sangut, serta tokoh Cenk dan Sangut. Hal ini sesuai dengan isi cerita wayang Cenk Blonk tersebut, yaitu menceritakan perjuangan, usaha, serta kerja keras Sang Gatutkaca dalam menunaikan tugas yang diberikan oleh ayahhandanya, Sang Bima, untuk mencari seorang istri. Perjalanan Sang Gatutkaca dalam usaha menemukan seorang istri tidaklah mudah. Banyak rintangan dan ujian dalam usaha Sang Gatutkaca menyelesaikan tugasnya. Pada akhirnya, usaha Sang Gatutkaca berbuah manis dengan mendapatkan seorang istri yang sangat ideal. Usaha dan kerja keras Sang Gatutkaca dilakukan dengan tulus ikhlas tanpa meminta imbalan atau bantuan dari siapapun. Sang Gatutkaca bekerja keras untuk mewujudkan sesuatu atau apa yang diinginkan. Sehingga apa yang menjadi tujuan dan keinginan, tercapai dengan sempurna.

Hasil yang diperoleh untuk masalah yang kedua adalah, nilai-nilai karakter dalam dialog tokoh Cenk dan Blonk yang sudah digunakan dalam RPP oleh guru pengajar Bahasa Indonesia di kelas VII SMPN 3 Denpasar adalah, nilai karakter Religius, nilai karakter Tanggung Jawab, nilai karakter Kerja Keras, dan nilai karakter Menghargai Prestasi. Nilai-nilai karakter dalam dialog tokoh Cenk dan Blonk yang diterapkan dalam RPP oleh guru pengajar Bahasa Indonesia di kelas VIII SMPN 3 Denpasar adalah, nilai karakter Religius, nilai karakter Tanggung Jawab, dan nilai karakter Kerja Keras. Dan nilai-nilai karakter dalam dialog tokoh Cenk dan Blonk yang digunakan dalam RPP oleh guru pengajar Bahasa Indonesia di kelas IX SMPN 3 Denpasar adalah, Religius, Kerja Keras, Tanggung Jawab, dan Menghargai Prestasi.

Data dari hasil observasi guru pengajar antara lain, nilai-nilai karakter yang diterapkan oleh guru pengajar kelas VII dalam pelaksanaan pembelajaran t antara lain, nilai karakter Religius, nilai karakter Kerja Keras, nilai karakter Demokratis, dan nilai karakter Menghargai Prestasi. Guru pengajar kelas VIII menerapkan empat nilai pendidikan karakter, yaitu nilai karakter Religius, nilai karakter Tanggung Jawab, nilai karakter Demokratis, dan nilai karakter Mengharagai Prestasi. Guru kelas IX menerapakan enam nilai karakter, yaitu nilai karakter Religius, nilai karakter Kerja Keras, nilai karakter Tanggung Jawab, nilai karakter Peduli Sosial, dan nilai karakter Menghargai Prestasi.

Pada tahap evaluasi pembelajaran Bahasa Indonesia di kelas VII, VIII, dan IX, hanya guru pengajar Bahasa Indonesia di kelas IX yang menerapkan dan mencantumkan nilai karakter di dalam contoh soal ulangan harian.

Pemilihan dan penggunaan nilai pendidikan karakter oleh guru sebagai alternatif materi dalam proses perencanaan, pelaksanaan, dan evaluasi pembelajaran Bahasa Indonesia di kelas VII, VIII, dan IX adalah penerapan yang tidak disadri oleh guru, artinya, guru tidak mengetahui bahwa di dalam RPP, pelaksanaan pembelajaran, dan evaluasi pembelajaran, sebenarnya sudah dicantumkan beberapa nilai pendidikan karakter. Tidak semua nilai pendidikan karakter yang berjumlah delapan belas tersebut dicantumkan dan diterapkan oleh guru. Dan juga, tidak semua nilai karakter pendidikan yang ditemukan di dalam dialog tokoh Cenk dan Blonk yang diterapkan oleh guru.

Keseluruhan nilai karakter yang diterapkan oleh guru pengajar Bahasa Indonesia di kelas VII, VIII, dan IX, baik dalam proses perencanaan pembelajaran, pelaksanaan pembelajaran, dan evaluasi pembelajaran, tidak disampaikan secara tegas oleh guru, sehingga terkesan penerapannya dilakukan tanpa sadar. Keseluruhan nilai pendidikan karakter yang berjumlah delapan belas nilai, tidak kesemuanya diterapkan oleh masing-masing guru pengajar Bahasa Indonesia di kelas VII, VIII, dan IX.

Pemilihan dan penggunaan nilai pendidikan karakter oleh guru sebagai alternatif materi dalam proses perencanaan, pelaksanaan, dan evaluasi pembelajaran Bahasa Indonesia di kelas VII, VIII, dan IX adalah penerapan yang tidak disadri oleh guru, artinya, guru tidak mengetahui bahwa di dalam RPP, pelaksanaan pembelajaran, dan evaluasi pembelajaran, sebenarnya sudah dicantumkan beberapa nilai pendidikan karakter. Tidak semua nilai pendidikan karakter yang berjumlah delapan belas tersebut dicantumkan dan diterapkan oleh guru. Dan juga, tidak semua nilai karakter pendidikan yang ditemukan di dalam dialog tokoh Cenk dan Blonk yang diterapkan oleh guru.

Berdasarkan hasil wawancara dengan ketiga guru tersebut, didapat hasil bahwa mereka belum tahu tentang nilai karakter yang seperti apa yang harus diterapkan pada setiap proses pembelajaran di dalam kelas, terutama dalam perencanaan, pelaksanaan, dan evaluasi pembelajaran. Dalam hal ini, belum ada penjelasan dari pihak terkait (Dinas Pendidikan), 
pengawas, maupun dari pihak-pihak yang mengadakan workshop tentang pengimplementasian nilai-nilai pendidikan karakter dalam pembelajaran Bahasa Indonesia khususnya. Sehingga, penerapan nilai-nilai karakter tersebut diterapkan secara tidak langsung atau tanpa disadari.

Hal ini sesuai dengan hasil penelitian yang dilaksanakan oleh A.G. Sukalima tahun 2013 yang berjudul " Upaya Menanamkan Nilai-nilai Pendidikan Karakter dalam Pembelajaran Puisi di Kelas XI SMA Negeri 3 Singaraja", bahwa penerapan nilai-nilai karakter yang terdapat di dalam materi pembelajaran tidak terlalu banyak jumlahnya. Temuan ini sejalan pula dengan hasil penelitian yang dilaksanakan oleh D.M Wardika Yusana tahun 2013 yang berjudul " Pembelajaran Bahasa Indonesia Berbasis Pendidikan Karakter Bangsa Pada Siswa SMK Negeri 2 Tabanan", bahwa guru belum menerapkan nilai pendidikan karakter pada tahap evaluasi pembelajaran.

Kerelevansian penerapan nilai-nilai pendidikan karakter yang ditemukan di dalam dialogdialog tokoh Cenk dan Blonk sudah relevan dengan apa yang digariskan di dalam Kurikulum 2013, yaitu adanya pengimplementasian dan pengintegrasian nilai-nilai pendidikan karakter di dalam materi pembelajaran, salah satunya materi pembelajaran Bahasa Indonesia di kelas VII, VIII, dan IX. Relavansi ini terlihar dari apa yang dinyatakan oleh Zubaedi (2011: 355), bahwa format pembelajaran pendidikan karakter secara terpadu dipandang relevan dalam upaya mewujudkan karakter bangsa yang sedang terpuruk, seperti apa yang digambarkan di awal, di bagian latar belakang penelitian ini. Hal ini juga sejalan dengan konsep penerapan sikap dalam Kurikulum 2013, yaitu KI-1 (sikap spiritual) dan KI-2 (sikap sosial) diajarkan secara tidak langsung (indirect teaching) melalui KI-3 (pengetahuan), dan KI-4 (keterampilan).

Pendidikan karakter dapat diintegrasikan dalam pembelajaran pada setiap mata pelajaran. Materi-materi pembelajaran yang berkaitan dengan norma atau nilai-nilai pada setiap mata pelajaran perlu dikembangkan, dieksplisitkan, dikaitkan dengan konteks kehidupan seharihari. Menurut Mahsun (2014: 117), peserta didik dapat memperkaya wawasan akan nilai-nilai kemanusiaan yang universal yang terdapat di dalam sebuah teks yang dibaca. Dengan demikian, pembelajaran berbasis teks dapat menunjang pembelajaran yang menekankan kompetensi sikap (pembentukan moral anak bangsa).

Sejalan dengan hal tersebut, Kemendiknas (2010) dalam buku panduan pendidikan karakter di sekolah, dalam struktur pendidikan Nasional menyatakan bahwa yang dimaksud dengan pendidikan karakter secara terintegrasi di dalam mata pelajaran adalah pengenalan nilai-nilai, diperolehnya kesadaran akan pentingnya nilai-nilai, dan penginternalisasian nilai-nilai ke dalam tingkah laku peserta didik sehari-hari melalui proses pembelajaran yang berlangsung di dalam maupun luar kelas pada semua mata pelajaran. Pada dasarnya kegiatan pembelajaran, selain untuk menjadikan peserta didik menguasai kompetensi (materi) yang diajarkan, juga dirancang untuk menjadikan peserta didik mengenal, menyadari/peduli, dan menginternalisasi nilai-nilai yang menjadikannya perilaku.

Menurut Damayanti, (2014: 93) pembelajaran Bahasa Indonesia memiliki potensi yang sangat besar untuk dijadikan media pendidikan karakter. Hal ini berkaitan dengan pembelajaran keterampilan berbahasa, yang terlibat dalam semua aspek dan konteks kehidupan. Pendidikan karakter dapat diintegrasikan ke dalam empat pembelajaran keterampilan berbahasa, yaitu keterampilan mendengarkan, berbicara, membaca, dan menulis. Dalam pembelajaran Bahasa Indonesia, sebaiknya empat leterampilan berbahasa tersebut tidak disajikan secara terpisah, tetapi dikemas secara terpadu. Melalui pembelajaran terpadu itulah, integrasi pendidikan karakter di dalam pembelajaran Bahasa Indonesia menjadi semakin mudah dan memiliki cakupan yang luas.

Berdasarkan analisis data pelaksanaan kegiatan pembelajaran oleh guru pengajar Bahasa Indonesia di kelas VIII, VIII, dan IX, pengintegrasian, penerapan, dan pemilihan nilainilai pendidikan karakter sebagai alternatif materi sudah relevan dengan materi, serta empat keterampilan berbahasa, yakni, mendengarkan, berbicara, membaca, dan menulis. Relevansi tersebut terlihat dari kegiatan guru dan siswa di dalam kelas pada saat kegiatan pembelajaran berlangsung. Nilai-nilai pendidikan karakter seperti nilai karakter Disiplin diterapkan oleh guru pada saat menyampaikan tujuan pembelajaran, dan siswa secara antusias mendengarkan apa yang disampaikan oleh guru. Nilai karakter Tanggung Jawab diintegrasikan guru dalam kegiatan siswa yang ditunjuk dan diberikan sebuah permasalahan, kemudian siswa berani ke depan kelas atau di tempat duduknya untuk memecahkan dan menjawab pertanyaan dari gurunya. Nilai karakter Gemar Membaca diterapkan dan diintegrasikan oleh guru pada saat siswa diminta untuk membaca buku yang diminati oleh siswa, sebelum pembelajaran dimulai. Program membaca ini dilaksanakan kurang lebih sepuluh menit sebelum kegiatan inti pembelajaran dimulai. Dan nilai karakter Kerja Keras diterapkan dan dintegrasikan oleh guru 
dalam kegiatan siswa yang diminta untuk menentukan struktur sebuah teks yang sedang dipelajari.

Penerapan nilai pendidikan karakter di dalam pembelajaran Bahasa Indonesia baik di dalam perencanaan pembelajaran, pelaksanaan pembelajaran, dan evaluasi pembelajaran, sudah dilaksanakan oleh guru, walaupun penerapan tersebut tanpa disadari, atau secara tidak tegas dilaksanakan. Hal ini sesuai dengan apa yang dinyatakan oleh Zubaedi (2011: 355), bahwa format pembelajaran pendidikan karakter secara terpadu dipandang relevan dalam upaya mewujudkan karakter bangsa yang sedang terpuruk, seperti apa yang digambarkan di awal, di bagian latar belakang penelitian ini. Hal ini juga sejalan dengan konsep penerapan sikap dalam Kurikulum 2013, yaitu KI-1 (sikap spiritual) dan KI-2 (sikap sosial) diajarkan secara tidak langsung (indirect teaching) melalui KI-3 (pengetahuan), dan KI-4 (keterampilan).

Zubaedi, (2011:5) mengatakan bahwa, pendidikan karakter perlu dimulai dengan penanaman pengetahuan dan kesadaran kepada anakakan bagaimana bertindak sesuai nilainilai moralitas, sebab jika anak tidak tahu bagaimana bertindak, perkembangan moral mereka akan terganggu.

Proses pendidikan karakter tidak mudah untuk dibangun pada setiap individu maupun kelompok, Karena dalam prosesnya, banyak faktor yang menentukan keberhasilan dalam membentuk manusia berkarakter. Kekuatan dalam proses pembentukan karakter sangat ditentukan oleh realitas sosial yang bersifat subjektif yang dimiliki individu dan realitas objektif di luar individu yang mempunyai pengaruh yang sangat kuat dalam membentuk pribadi yang berkarakter.

\section{Simpulan dan Saran}

Berdasarkan masalah yang diajukan, hasil kajian Nilai Pendidikan Karakter dalam Dialog Tokoh Cenk-Blonk pada Lakon Wayang Cenk Blonk Berjudul "Gatutkaca Duta" Sebagai Alternatif Materi pada Pembelajaran Bahasa Indonesia di SMPN 3 Denpasar, dapat disimpulkan sebagai berikut. Dalam cerita dari lakon wayang inovatif Cenk Blonk yang berjudul Gatutkaca Duta, ditemukan sembilan buah nilai karakter dalam dialog tokoh Cenk dan tokoh Blonk, yaitu (1) Religius, (2) Kerja Keras, (3) Tanggung Jawab, (4) Demokratis, (5) Menghargai Prestasi, (6) Toleransi, (7) Peduli Sosial, (8) Cinta Damai, dan (9) Cinta Tanah Air. Hal ini menandakan bahwa, tidak semua dari kedelapan belas nilai pendidikan karakter dapat dimasukkan ke dalam lakon wayang Cenk Blonk yang berjudul Gatutkaca Duta, pun sama halnya dengan nilai-nilai pendidikan karakter yang ditemukan di dalam dialog-dialog antara tokoh Cenk dan tokoh Blonk, baik juga antara tokoh Cenk dan Blonk dengan tokoh lainnya.

Nilai-nilai pendidikan karakter yang ditemukan di dalam dialog-dialog tokoh Cenk dan Blonk sudah diterapkan dan diintegrasikan sebagai alternatif materi dalam ketiga proses pembelajaran Bahasa Indonesia, yaitu di kelas VII, guru menerapkan empat buah nilai pendidikan karakter pada perencanaan pembelajaran (RPP), yaitu nilai pendidikan karakter Religius, Kerja Keras, Tanggung Jawab, dan Menghargai Prestasi. Pada tahap pelaksanaan pembelajaran, guru menerapkan empat buah nilai pendidikan karakter, yaitu nilai pendidikan karakter Religius, Kerja Keras, Demokratis, dan Menghargai Prestasi. Dan pada tahap evaluasi, guru tidak menerapkan nilai pendidikan karakter di dalam soal evaluasi pembelajarannya. Guru pengajar Bahasa Indonesia di kelas VIII menerapakan tiga buah nilai pendidikan karakter di dalam perencanaan pembelajarannya (RPP), yaitu nilai pendidikan karakter Religius, Tanggung Jawab, dan Kerja Keras. Pada tahap observasi, guru menerapkan empat buah nilai pendidikan karakter, yaitu nilai pendidikan karakter Religius, Demokratis, Tanggung Jawab, dan Menghargai Prestasi. Pada tahap evaluasi, guru tidak menerapkan nilai pendidikan karakter. Dan guru pengajar Bahasa Indonesia di kelas IX, menerapkan empat buah nilai pendidikan karakter dalm perencanaan pembelajarannya (RPP), yaitu nilai pendidikan Religius, Tanggung Jawab, Menghargai Prestasi, dan Kerja Keras. Pada tahap pelaksanaan pembelajaran, guru menerapkan lima buah nilai pendidikan karakter, yaitu nilai pendidikan karakter Religius, Tanggung Jawab, Kerja Keras, Peduli Sosial, dan Menghargai Prestasi. Dan pada tahap evaluasi, guru menerapkan dua buah nilai pendidikan karakter yang ditemukan di dalam dialog tokoh Cenk dan Blonk, yaitu nilai karakter Peduli Sosial, dan Cinta Damai.

Berdasarkan temuan dalam penelitian ini, ada beberapa saran yang ingin diberikan melalui penelitian ini, yaitu sebagai berikut.

Siapapun yang akan memanfaatkan pendidikan karakter, penelitian ini dapat digunakan sebagai refrensi bagi perkembangan dan kemajuan ilmu pengetahuan, khususnya dalam penerapan nilai-nilai pendidikan karakter dalam pembelajaran Bahasa Indonesia. 
Berdasarkan hasil penelitian ini, guru, terutama guru pengajar Bahasa Indonesia SMP hendaknya menggunakan nilai-nilai karakter pendidikan sebagai salah satu alternatif materi di dalam setiap pembelajaran Bahasa Indonesia yang meliputi proses perencanaan pembelajaran, pelaksanaan pembelajaran, dan evaluasi pembelajaran.

Guru Bahasa Indonesia disarankan lebih kreatif dalam mencari sumber-sumber pembelajaran yang berkaitan dengan penerapan, pengembangan, danpenerapan nilai-nilai pendidikan karakter. Salah satunya dengan menjadikan seni pertunjukkan wayang Cenk Blonk sebagai sebuah refrensi menggali nilai-nilai pendidikan karakter yang nantinya bisa diimplementasikan dalam pembelajaran Bahasa Indonesia tingkat SMP kelas VII, VIII, dan IX.

Pihak sekolah dan Dinas Pendidikan hendaknya memberikan pelatihan-pelatihan secara berkala tentang penerapan nilai-nilai pendidikan karakter kepada guru dalam proses pembelajaran baik dari segi perencanaan (RPP), pelaksanaan pembelajaran, dan evaluasi pembelajaran, khususnya dalam mata pelajaran Bahasa Indonesia.

\section{Daftar Pustaka}

Damayanti, Deni. 2014. Panduan Implementasi Pendidikan Karakter Di Sekolah. Yogyakarta: Araska.

Kementrian Pendidikan dan Kebudayaan. 2013. Peraturan Menteri Pendidikan Dan Kebudayaan Republik Indonesia Nomor 68 Tahun 2013, Tentang Kerangka Dasar Dan Struktur Kurikulum Sekolah Menengah Pertama/Madrasah Tsanawiah.Jakarta ; Kemendikbud.

Mahsun. 2014. Teks Dalam Pembelajaran Bahasa Indonesia Kurikulum 2013. Jakarta: Raja Grafindo Persada.

Pusat Kurikulum Departemen Pendidikan Nasional. 2010. Bahan Pelatihan Pengantar Metodologi Pembelajaran Berdasarkan Nilai-nilai Budaya untuk Membentuk Daya Saing dan Karakter Bangsa. Jakarta; Kemendikbud.Alfabeta.

Sukalima, AG. 2013. Upaya menanamkan Nilai-nilai Pendidikan Karakter Dalam Pembelajaran Puisi Di Kelas X SMA Negeri 3 Singaraja. E-Journal Program Pascasarjana Universitas Pendidikan Ganesha Program Studi Pendidikan Bahasa Indonesia Volume 2 Tahun 2013.

Tohir.http//www.srtikelsiana.com/2014/08/pengertianpendidikan-tujuan-manfaat/html.(tidak diterbitkan)

Yusana Wardika, D.M. 2013. Pembelajaran Bahasa Indonesia Berbasis Karakter Bangsa Pada Siswa SMK Negeri 2 Tabanan. E-Journal Program Pascasarjana Universitas Pendidikan Ganesha Program Studi Pendidikan Bahasa Indonesia Volume 2 Tahun 2013.

Zubaedi. 2012. Desain Pendidikan Karakter : Konsepsi dan Aplikasinya Dalam Lembaga Pendidikan. Jakarta ; Kencana Prenada Media Group. 